\section{Eradication of Salmonella Typhimurium in broiler chicks by combined use of P22 bacteriophage and probiotic}

\author{
Guilherme Augusto Marietto-Gonçalves, ${ }^{1}$ \\ Edna Tereza Lima, ${ }^{2}$ Tais Cremasco \\ Donato, ${ }^{1}$ Ticiane Sousa Rocha, ${ }^{1}$ \\ Luis Emiliano Cisneros Álvarez, ${ }^{1}$ \\ Júlio Lopes Sequeira, ${ }^{1}$ \\ Raphael Lucio Andreatti Filho' \\ ${ }^{1}$ Avian Pathology Laboratory, \\ Department of Veterinary Clinical \\ Sciences, School of Veterinary Medicine \\ and Animal Science, São Paulo State \\ University, Botucatu; \\ 2Paraná State Federal University, \\ Palotina, Brazil
}

\begin{abstract}
It has been reported that the phage therapy is effective in controlling the number of colony-forming unit (CFU) of Salmonella spp. in chicken gut. This paper describes the protective effect of phage and Lactobacilli administration on Salmonella infection in 1-day-old chicks. We administered the bacteriophage P22 in a single dose and a probiotic mixture of four species of bacteriocin-producing Lactobacillus once a day for one week. Samples were analyzed every 48 hours, and intestinal eradication of S. Typhimurium was confirmed after treatments. We observed an increase in the size of duodenal villi and cecal crypts, as well as an increase in body weight in groups that received daily doses of Lactobacilli. This study confirms the efficiency of bacteriophage therapy in controlling salmonellosis in chicks and the beneficial effect of Lactobacilli mixtures in the weight gain of the birds.
\end{abstract}

\section{Introduction}

Bacteriophages are host-specific viruses that infect bacteria and are not able to damage either eukaryotic cells or other than their target-bacteria. $^{1-5}$ P22 is a lambdoid bacteriophage species that infects Salmonella serogroups A, B, and D1; such group can be identified by the trisaccharide sequence of the somatic antigen $\alpha$-D-mannose- $(1 \rightarrow 4)$ - $\alpha$-Lrhamnose- $(1 \rightarrow 3)-\alpha$-D-galactose- $(1 \rightarrow 4)$. This phage attaches to the target-cell's wall, subsequently cleaving the glycosidic linkage rhamnose- $(1 \rightarrow 3)$ - $\alpha$-D-galactose due to tailspike enzymes with endoglycosidic activity. ${ }^{3}$ P22 uses such enzymes to perforate the cell's wall by injecting its DNA into Salmonella in order to replicate. ${ }^{4}$ After virion production, lytic bacteriophages cause the rupture of the host cells. $^{5}$

Salmonella are rod-shaped, Gram-negative bacteria that belong to the family Enterobacteriaceae. There are three recognized species of Salmonella: S. subterranea, isolated from soil, $S$. bongori, typically isolated from cold-blooded animals, and $S$. enterica, isolated from warm-blooded animals. The latter is composed by six subspecies (enterica, salamae, arizonae, diarizonae, houtenae, and indica) and approximately 2500 serovars, including the bird-specific types Pullorum and Gallinarum..$^{6-9}$ Salmonella enterica subspecies enterica serovars Enteritidis and Typhimurium are usually present in birds as the main cause of paratyphus in Brazil and USA, the latter serovar also being responsible for food-borne infection in man. ${ }^{10-12}$ Other serovars commonly isolated are Agona, Anatum, Cubana, Handar, Heidelberg, Mbandaka, Montevideo, and Senftenberg. ${ }^{12}$

The prevention of Salmonella infections can be performed by using probiotics, which reduce the number of these pathogenic bacteria with considerable success. Lactobacillus is probably the most important genus of lactic acid bacteria used for probiotic production in poultry industry. These bacteria have several strategies to inhibit or even kill other bacterial species, such as the direct competition for linkage sites on the epithelial surfaces and also for nutrients available at the intestinal lumen. ${ }^{13}$ Additionally, there is a release of several metabolic products with antibacterial activity that increase the efficiency of Lactobacillus in competing with other microorganisms, i.e. lactic and acetic acid, ${ }^{14,15}$ which modify the luminal $\mathrm{pH}$ consequently difficulting the survival of other bacteria; hydrogen peroxide, ${ }^{16}$ which affects proteins and destroys nucleic acids from other bacteria; and the production of the so called bacteriocins, which are complex proteins that result from the catabolism of the lactic acid with bacteriocidal effect. $^{17}$

The worldwide increase in bacterial resistance stimulated the search for alternative strategies to control salmonellosis. The use of phage therapy and probiotics for such purpose is highlighted since they offer advantages such as the lack of residual substances remaining in animal products and absence drug resistance. ${ }^{18}$ Accordingly, the aim of this study was to verify the efficiency of the combined administration of the P22 bacteriophage and a Lactobacilli-based probiotic as an experimental treatment in order to eradicate Salmonella in chicks. Additionally, we also aimed to verify possible alterations in intestinal microenvi-
Correspondence: Guilherme Augusto MariettoGonçalves. Laboratório de Ornitopatologia, Departamento de Clínica Veterinária, Faculdade de Medicina Veterinária e Zootecnia, UNESP, caixa postal 560, Zip code 18618-000, Botucatu, São Paulo, Brasil.

Tel./fax. +55.14.3811.6293.

E-mail: gmarietto_ornito@fmvz.unesp.br

Key words: bacteriophage, intestinal microbiology, probiotic, Salmonella.

Acknowledgments: we thank the São Paulo Research Foundation (Fundação de Amparo à Pesquisa do Estado de São Paulo - FAPESP) for providing the master grant 07/54012-9 to Guilherme Augusto Marietto Gonçalves and the research grant 08/51034-4 for Raphael Lúcio Andreatti Filho.

Received for publication: 20 March 2011.

Revision received: 21 May 2011.

Accepted for publication: 21 May 2011.

This work is licensed under a Creative Commons Attribution 3.0 License (by-nc 3.0).

(C) Copyright G.A. Marietto-Gonçalves et al., 2011 Licensee PAGEPress, Italy

Microbiology Research 2011; 3:e2

doi:10.4081/mr.2011.e2

ronment morphology and changes in birds' weight gain.

\section{Materials and Methods}

\section{Birds}

Three hundred eighty-four, one-day-old, Salmonella free chicks, lineage Avian Farm (Gallus gallus domesticus) were housed at the avian center of the Avian Pathology Laboratory, Department of Veterinary Clinical Sciences, School of Veterinary Medicine and Animal Science and Animal Sciences, São Paulo State University - UNESP, Botucatu, Brazil. The study was approved by the Ethics Committee on Animal Experimentation of the School of Veterinary Medicine and Animal Science, UNESP, Botucatu, Brazil. Antibiotic-free food and water were provided ad libitum. Confirmation of the absence of Salmonella spp. in the birds was evaluated before use through microbiological tests. Twelve extra birds were euthanized by cervical dislocation and the liver, caecum and yolk sacs were aseptically collected. The organs were then incubated overnight at $37^{\circ} \mathrm{C}$ in tubes containing $10 \mathrm{~mL}$ of Tetrathionate Broth (TB; Merck, Darmstadt, Germany) and Selenite-Cistine Broth (SCB; Merck, Darmstadt, Germany). The enriched samples were plated on Brilliant Green Agar 
(BGA; 0xoid, Basingstoke, England) and Xylose-Lysine Desoxycholate Agar (XLD; Oxoid, Basingstoke, England) and incubated overnight at $37^{\circ} \mathrm{C}$. Each plate was evaluated for the presence or absence of lactose negative colonies.

\section{Culture and preparation of}

Salmonella Typhimurium inoculums

We used a laboratory induced nalidixic acidresistant strain of ST from the Avian Pathology Laboratory, UNESP, Botucatu, Brazil. The initial culture was produced by adding $3 \mathrm{~mL}$ of turbid broth of ST in $50 \mathrm{~mL}$ of nutrient broth and incubated at $40^{\circ} \mathrm{C}$ for 24 hours. Then, ST colonyforming units (CFU) were calculated immediately before inoculation by performing decimal serial dilutions using phosphate-buffered saline (PBS) $\mathrm{pH}$ 7.2. The diluted sample $(0.1 \mathrm{~mL})$ was placed in Petri plates containing BGA supplemented with $100 \mu \mathrm{g} / \mathrm{mL}$ of nalidixic acid, and cultivated for 24 hours at $40^{\circ} \mathrm{C}$. Birds in groups $\mathrm{St}, \mathrm{St}+\mathrm{Pb}, \mathrm{St}+\mathrm{Ph}$ and $\mathrm{St}+\mathrm{Pb}+\mathrm{Ph}$ were intraesophageal gavage with $0.5 \mathrm{~mL}$ of culture containing $4 \times 10^{4} \mathrm{CFU} / \mathrm{mL}$ of ST.

\section{Culture and use of the probiotic}

The probiotic was formulated using Lactobacillus acidophilus, L. fermentum, L. reuteri, and $L$. salivarius strains from the Avian Pathology Laboratory, UNESP, Botucatu, Brazil. Strains were initially overnight incubated using DeMan-Rogosa-Sharpe medium (MRS; Oxoid, Basingstoke, England) in a jar with Anaerobac System (Probac do Brasil Ltda., Sao Paulo, Brazil) at $37^{\circ} \mathrm{C}$, and then placed in MRS medium and overnight reincubated in anaerobiosis at $37^{\circ} \mathrm{C}$. The inhibitory effect of the Lactobacilli strains on ST was confirmed using the Spot-on-the-lawn method, as described by Lima et al. ${ }^{19}$ Lactobacilli species were individually cultivated every 24 hours, and mixed immediately before inoculation. Decimal serial dilutions of Lactobacilli cultures were performed in order to quantify CFU using the same technique previously described for ST, except for the use of MRS as the medium and $37^{\circ} \mathrm{C}$ as temperature set. The birds of groups $\mathrm{Pb}, \mathrm{St}+\mathrm{Pb}, \mathrm{St}+\mathrm{Pb}+\mathrm{Ph}$ and $\mathrm{Pb}+\mathrm{Ph}$ were treated every 24 hours by intraesophageal gavage using $0.5 \mathrm{~mL}$ containing $6 \times 10^{9} \mathrm{CFU} / \mathrm{mL}$ of probiotic.

\section{Culture and use of the bacterio- phage}

A sample of P22 bacteriophage (ATCC 19585-B1) from the Brazilian Agricultural Research Corporation (EMBRAPA), Embrapa Food Technology research center - Rio de Janeiro, Brazil - was used. For P22 culture, a nutrient broth (Acumedia, Lansing, USA) $1 \mathrm{~mL}$ solution with $0.5 \%$ of $\mathrm{NaCl}$ containing $2 \times 10^{10}$
P22 CFU and $3 \mathrm{~mL}$ of turbid pre-culture containing ST in tryptone soy broth (TSB) (Merck, Darmstadt, Germany) at double concentration were added to $5 \mathrm{~mL}$ of TSB with subsequent homogenization. After four hours at $40^{\circ} \mathrm{C}$, the solution was filtered using a $0.22 \mu \mathrm{m}$ porosity micro-filter (Medical Millex-GS filter unity, Millipore, Billerica, USA). Subsequently, quantification of plaque-forming units (PFU) was performed in order to obtain P22 concentration. For such purpose, $100 \mu \mathrm{L}$ serial dilutions of the P22 filtrate (i.e. $1^{-1}$ to $1^{-10}$ ) were placed in polypropylene microtubes containing $0.9 \mathrm{~mL}$ of PBS, subsequently discharging $100 \mu \mathrm{L}$ of solution from the last recipient. Posteriorly, $1 \mathrm{~mL}$ of a pre-culture of ST in TSB at double concentration was diluted in $9 \mathrm{~mL}$ of PBS. The total volume of P22 each dilution and $100 \mu \mathrm{L}$ of ST 1:9 were placed in tubes with $3 \mathrm{~mL}$ of TSB soft agar (warmed in boiling bath at $50^{\circ} \mathrm{C}$ ), homogenized, distributed in sterile Petri plates, and kept at room temperature until solidification, using the technique by Debartolomeis and Cabelli ${ }^{20}$ modified by the authors. Before PFU quantification, plates were overnight incubated at $40^{\circ} \mathrm{C}$. Subsequently, birds of groups $\mathrm{Ph}, \mathrm{St}+\mathrm{Ph}$, $\mathrm{St}+\mathrm{Pb}+\mathrm{Ph}$ and $\mathrm{Pb}+\mathrm{Ph}$ were inoculated by intraesophageal gavage with $0.5 \mathrm{~mL}$ of the mixture containing 3 x 1010 PFU/mL of P22.

\section{Inoculums}

Birds were divided into eight groups of 48 individuals each. All groups were identified using specific characters (Table 1). Monitoring of Salmonella and bacteriophage colonization, evaluation of length of intestinal villi, and weight gain rate measurements were performed during the experiment. Prior of inoculations, all birds were submitted to overnight fasting. In the first day, birds in groups $\mathrm{St}, \mathrm{St}+\mathrm{Pb}, \mathrm{St}+\mathrm{Ph}$, and $\mathrm{St}+\mathrm{Pb}+\mathrm{Ph}$ were intraesophageally challenged with Salmonella Typhimurium (ST). Three hours later, groups $\mathrm{Ph}, \mathrm{St}+\mathrm{Ph}, \mathrm{St}+\mathrm{Pb}+\mathrm{Ph}$ and $\mathrm{Pb}+\mathrm{Ph}$ were given by intraesophageal gavage with the bacteriophage inoculums, and groups $\mathrm{Pb}, \mathrm{St}+\mathrm{Pb}$, $\mathrm{St}+\mathrm{Pb}+\mathrm{Ph}$, and $\mathrm{Pb}+\mathrm{Ph}$ were intraesophageally treated with a probiotic. Treatment with probi-

Table 1. Identification of the experimental groups related to the treatment.

\begin{tabular}{llc} 
Group & Treatment & Number of birds \\
$\mathrm{Cr}$ & Control* & 48 \\
$\mathrm{St}$ & Salmonella Typhimurium & 48 \\
\hline $\mathrm{Pb}$ & Probiotic & 48 \\
$\mathrm{Ph}$ & Bacteriophage P22 & 48 \\
\hline $\mathrm{St}+\mathrm{Pb}$ & Salmonella Typhimurium and probiotic & 48 \\
$\mathrm{St}+\mathrm{Ph}$ & Salmonella Typhimurium and bacteriophage P22 & 48 \\
\hline $\mathrm{St}+\mathrm{Pb}+\mathrm{Ph}$ & Salmonella Typhimurium, probiotic and bacteriophage P22 & 48 \\
$\mathrm{~Pb}+\mathrm{Ph}$ & Probiotic and bacteriophage P22 & 48
\end{tabular}

otic was repeated every 24 hours until 144 hours from the start of the experiment. Sampling was performed every 48 hours from the beginning of the treatments: I-0 hour, II-48 hours, III-96 hours and IV-144 hours. During each collection 12 birds were taken from each group in order to perform the tests.

\section{Evaluation of body weight and intestinal villi morphometry}

Body weight was obtained using a digital scale with a $500 \mathrm{~g}$ limit. Birds were euthanithized by cervical dislocation (according to the resolution 714, June 2002, Federal Council of Veterinary Medicine, Brazil) for collection of duodenum and cecum. For morphometrical analysis samples from the second third of the duodenum including the pancreas and from the distal portion of the cecum (blind fundus) were collected. Samples were washed with a continuous injection of Bouin's solution for removing intestinal content, Bouin-fixed, and paraffin-embedded. Posteriorly, three semi-seriated $5 \mu \mathrm{m}$-thick section were obtained, hematoxylin and eosin stained and observed under light microscopy. Slides were analyzed with the Zeiss Axio Imager A1 microscope using the Axio Vision Software Rel. version 4.6.1 (Carl Zeiss MicroImaging, Heildelberg, Germany). Ten duodenal villi and cecal crypts were evaluated in each section in order to obtain morphometric results.

\section{Microbiological monitoring}

The monitoring for identifying ST and P22 was achieved by using polymerase chain reaction (PCR) and microbiological isolation from cecum and feces. Ceci were collected at predetermined moments (i.e. I-0 hour, II-48 hours, III-96 hours and IV-144 hours) and feces were daily collected from the bottom of the cages. Cecum and feces were evaluated as pooled samples in order to increase the chances of detection and isolation of ST and P22. Samples were mashed and $2 \mathrm{~g}$ were suspended in $25 \mathrm{~mL}$ of PBS. The material was vortexed and filtered in order to remove larger particles, and $1 \mathrm{~mL}$ of the filtered solution was used for DNA extraction using Chelex-100 ${ }^{\mathrm{TM}}$ (Biorad Laboratories,

\footnotetext{
*Group without treatment.
} 
Richmond, USA). The filtered samples were vortexed in polypropylene tubes, followed by centrifugation at $3,000 \mathrm{rpm}$ for $10 \mathrm{~min}$ at $5^{\circ} \mathrm{C}$. Supernatant was removed and the pellet was discharged. Ten $\mu \mathrm{L}$ of chloroform was added to $100 \mu \mathrm{L}$ of the supernatant, gently hand-stirred for $30 \mathrm{sec}$ and incubated for $10 \mathrm{~min}$ at $5{ }^{\circ} \mathrm{C}$. After incubation, the material was centrifuged at $1,000 \mathrm{rpm}$ for $15 \mathrm{~min}$ at $5^{\circ} \mathrm{C}$, and $30 \mu \mathrm{L}$ of the supernatant was added to $30 \mu \mathrm{L}$ of Chelex$100^{\mathrm{TM}}$ at $5 \%$, subsequently obtaining a 1:1 concentration. The solution was incubated in a MasterCycler Gradient thermocycler (Eppendorf, Hamburg, Germany) at $99^{\circ} \mathrm{C}$ for 10 min and the supernatant containing free DNA was collected. Primers for the reaction were synthesized by Invitrogen Corporation (São Paulo, Brazil) and suspended at concentration of $10 \rho \mathrm{mol}$. For P22, the SieB gene (forward 5'ATGGTGGCAGGAGTTAATGC-3' and reverse 5'CAAACAAATCCCGAACGACT-3) was used with the following amplification program: $1 \mathrm{~min}$ at $94^{\circ} \mathrm{C}, 30$ cycles of amplification $\left(30 \mathrm{sec}\right.$ at $90^{\circ} \mathrm{C}$, $30 \mathrm{sec}$ at $58^{\circ} \mathrm{C}$, and $60 \mathrm{sec}$ at $72^{\circ} \mathrm{C}$ ), followed by a final polymerization for $8 \mathrm{~min}$ at $72^{\circ} \mathrm{C}$, as described by Mikasová et al. ${ }^{21}$ For ST the invA gene (forward 5'-TTGTTACGGCTATTTTGACCA$3^{\prime}$ and reverse 5'-CTGACTGCTACCTTGCTGATG-3) was used with the following amplification program: $5 \mathrm{~min}$ at $94^{\circ} \mathrm{C}, 35$ cycles of amplification ( $30 \mathrm{sec}$ at $94^{\circ} \mathrm{C}, 30 \mathrm{sec}$ at $60^{\circ} \mathrm{C}$, and $30 \mathrm{sec}$ at $72^{\circ} \mathrm{C}$ ) followed by a final polymerization for 4 minutes at $72^{\circ} \mathrm{C}$, as described by Swamy et al. ${ }^{22}$ Amplifications were carried out using $5 \mu \mathrm{L}$ of each sample added to $1 \mu \mathrm{L}$ of each primer, $12.5 \mu \mathrm{L}$ of the amplification kit Go Taq Green Master Mix (Promega, Madison, USA), and $5.5 \mu \mathrm{L}$ of ultrapure water. Microbiological isolation was carried out using the material processed in natura i.e. caecum and feces mashed and suspended in PBS. For recovery of ST, 1mL of each suspension was overnight incubated at $37^{\circ} \mathrm{C}$ in tubes containing $9 \mathrm{~mL}$ of TB and SCB. Samples were then plated in BGA and XLD added with $100 \mu \mathrm{g} / \mathrm{mL}$ of nalidixic acid, subsequently being overnight incubated at $37^{\circ} \mathrm{C}$. The presence or absence of lactose negative colonies was evaluated on each plate. For recovery of P22 the remaining suspension was filtered using a $0.22 \mu \mathrm{m}$ microfilter syringe. Then, $1 \mathrm{~mL}$ of the filtrate was placed into $5 \mathrm{~mL}$ of TSB/3 $\mathrm{mL}$ of turbid pre-culture of ST, and incubated for four hours at $40^{\circ} \mathrm{C}$. After filtration, $900 \mu \mathrm{L}$ were placed in $3 \mathrm{~mL}$ of TSB soft agar along with $100 \mu \mathrm{L}$ of 1:9 ST turbid preculture in order to confirm the formation of viral plaques.

\section{Statistical analysis}

The Scott-Knott test was used to compare statistical differences. Statistical analyses were performed using the SISVAR software (Universidade Federal de Lavras, Brazil) version 4.0 as described by Ferreira. ${ }^{23}$

\section{Results}

\section{Microbiological evaluation}

In all collections, ST was detected by both PCR and microbiologic isolation from the ceci of the St group. ST Fecal shedding was not detected by any of the methods here used. P22 was detected neither in the ceci nor in feces (Table 2).

\section{Weight gain rate}

The weight gain rates obtained during the four collections are summarized in Table 3 . The groups with similar weights during the first collection did not reveal statistically significant differences. With the exception of the St group, the groups showed continuous weight gain $(\mathrm{P}<0.05)$. Birds treated with probiotic had a final weight mean higher than the others, such as in the $\mathrm{St}+\mathrm{Pb}$ group; however, $\mathrm{Pb}$ and $\mathrm{St}+\mathrm{Pb}+\mathrm{Ph}$ groups did not reveal statistically significant differences between themselves. The $\mathrm{Cr}, \mathrm{Ph}, \mathrm{St}+\mathrm{Ph}$ and $\mathrm{Pb}+\mathrm{Ph}$ groups gained the same weight $(\mathrm{P}>0.05)$ and were lighter when compared to the $\mathrm{St}+\mathrm{Pb}, \mathrm{Pb}$ and $\mathrm{St}+\mathrm{Pb}+\mathrm{Ph}$ groups. The $\mathrm{St}$ group significantly lost weight $(\mathrm{P}<0.05)$ at the very beginning of the experiment, but gained weight after the third collection (96 hours). Nevertheless, the final weight of St group was significantly lower than those of the control group $(\mathrm{P}<0.05)$.

\section{Intestinal morphometry}

Results of the measurement of the duodenal villi and cecal crypts are summarized in Table 4. All of the groups had an increase in the mean size of duodenal villi and cecal crypts. The mean size of those structures in birds treated with Lactobacillus $(\mathrm{Pb}, \mathrm{St}+\mathrm{Pb}$, $\mathrm{St}+\mathrm{Pb}+\mathrm{Ph}$, and $\mathrm{Pb}+\mathrm{Ph}$ ) exceeded that of the other groups $(\mathrm{P}<0.05)$. The $\mathrm{Cr}, \mathrm{Ph}$, and $\mathrm{St}+\mathrm{Ph}$ groups revealed no statistically significant differences between themselves ( $\mathrm{P}>0.05)$. Additionally, cecal crypts were significantly shorter in the St group $(\mathrm{P}<0.05)$ when compared to other groups.

\section{Discussion}

Although paratyphus is relatively common in young birds, chicks older than 14 days rarely manifest clinical signs. ${ }^{24}$ With the exception of birds challenged with Salmonella, the chicks did not present clinical signs in this study, i.e. apathy, ruffled feathers, diarrhea, and mortali-

Table 2. Detection of Salmonella Typhimurium in caecum using PCR and conventional bacterial isolation (CFU) in the different treatments.

\begin{tabular}{lcccc} 
Group & \multicolumn{4}{c}{ Period after challenge (hours) * } \\
& 0 & 48 & 96 & 144 \\
$\mathrm{Cr}$ & $-/ \mathrm{ND}$ & $-/ \mathrm{ND}$ & $-/ \mathrm{ND}$ & $-/ \mathrm{ND}$ \\
$\mathrm{St}$ & $+/ 4 \times 10^{3}$ & $+/ 2 \times 10^{2}$ & $+/ 1 \times 10^{2}$ & $+/ 6 \times 10^{1}$ \\
\hline $\mathrm{Pb}$ & $-/ \mathrm{ND}$ & $-/ \mathrm{ND}$ & $-/ \mathrm{ND}$ & $-/ \mathrm{ND}$ \\
$\mathrm{Ph}$ & $-/ \mathrm{ND}$ & $-/ \mathrm{ND}$ & $-/ \mathrm{ND}$ & $-/ \mathrm{ND}$ \\
\hline $\mathrm{St}+\mathrm{Pb}$ & $-/ \mathrm{ND}$ & $-/ \mathrm{ND}$ & $-/ \mathrm{ND}$ & $-/ \mathrm{ND}$ \\
$\mathrm{St}+\mathrm{Ph}$ & $-/ \mathrm{ND}$ & $-/ \mathrm{ND}$ & $-/ \mathrm{ND}$ & $-/ \mathrm{ND}$ \\
\hline $\mathrm{St}+\mathrm{Pb}+\mathrm{Ph}$ & $-/ \mathrm{ND}$ & $-/ \mathrm{ND}$ & $-/ \mathrm{ND}$ & $-/ \mathrm{ND}$ \\
$\mathrm{Pb}+\mathrm{Ph}$ & $-/ \mathrm{ND}$ & $-/ \mathrm{ND}$ & $-/ \mathrm{ND}$ & $-/ \mathrm{ND}$
\end{tabular}

*Twelve birds Pool for each treatment. Negative: -. Positive: +. ND, no detected.

Table 3. Mean of body weight of birds challenged against Salmonella Typhimurium and treated with probiotic and bacteriophage P22. Results are expressed in grams (g).

\begin{tabular}{lcccc} 
Group & \multicolumn{4}{c}{$\begin{array}{c}\text { Period after challenge (hours) } \\
\text { a }\end{array}$} \\
$\mathrm{Cr}$ & 0 & 48 & 96 & 144 \\
$\mathrm{St}$ & $42.9 \pm 2.7 \mathrm{Dns}{ }^{\mathrm{b}}$ & $48.8 \pm 4.8 \mathrm{Ca}$ & $65.8 \pm 5.3 \mathrm{Bb}$ & $87.8 \pm 7.3 \mathrm{Ab}$ \\
$\mathrm{Pb}$ & $39.0 \pm 3.4 \mathrm{Bns} \mathrm{c}^{\mathrm{c}}$ & $35.4 \mathrm{a} \pm 3.3 \mathrm{Cb}$ & $45.0 \pm 4.1 \mathrm{Bc}$ & $60.3 \pm 11.9 \mathrm{Ac}$ \\
$\mathrm{Ph}$ & $42.6 \pm 2.6 \mathrm{Dns}$ & $47.9 \pm 5.4 \mathrm{Ca}$ & $76.6 \pm 9.7 \mathrm{Ba}$ & $104.9 \pm 10.9 \mathrm{Aa}$ \\
$\mathrm{St}+\mathrm{Pb}$ & $42.5 \pm 4.5 \mathrm{Dns}$ & $52.3 \pm 8.3 \mathrm{Ca}$ & $67.0 \pm 5.5 \mathrm{Bb}$ & $87.3 \pm 7.5 \mathrm{Ab}$ \\
$\mathrm{St}+\mathrm{Ph}$ & $41.2 \pm 2.8 \mathrm{Dns}$ & $52.3 \pm 6.1 \mathrm{Ca}$ & $80.4 \pm 5.3 \mathrm{Ba}$ & $115.3 \pm 10.4 \mathrm{Aa}$ \\
$\mathrm{St}+\mathrm{Pb}+\mathrm{Ph}$ & $43.3 \pm 3.1 \mathrm{Dns}$ & $51.7 \pm 6.8 \mathrm{Ca}$ & $63.9 \pm 6.7 \mathrm{Bb}$ & $91.4 \pm 7.1 \mathrm{Ab}$ \\
$\mathrm{Pb}+\mathrm{Ph}$ & $42.4 \pm 3.3 \mathrm{Dns}$ & $51.1 \pm 7.6 \mathrm{Ca}$ & $74.9 \pm 5.8 \mathrm{Ba}$ & $106.7 \pm 8.4 \mathrm{Aa}$ \\
\hline
\end{tabular}

aValues are arithmetic mean \pm standard deviation; ${ }^{b}$ Small letters compare the means of the treatments in each collection (column) and capital letters compare the means of the treatments during collections (lines). Values in a column and lines with different letters (e.g., a,b and c) differ significantly $(\mathrm{P}<0.05)$. ${ }^{\mathrm{N} S}$, no significant. 
ty. Birds of the St group presented discrete diarrhea in the first and second days after challenge and such diarrhea ceased in the consecutive days. Such results support those from Zhang et al., ${ }^{25}$ who documented that Salmonella inoculums containing $10^{4}$ to $10^{7}$ CFU may cause persistent diarrhea lasting from two to eight days in birds. The presence of clinical signs, microbiologic isolation, and PCR detection of ST from the intestines confirmed the efficiency of the inoculum used in this experiment.

In this study, no $\mathrm{P} 22$ recovery from ceci or feces was achieved. In $\mathrm{Ph}$ and $\mathrm{Pb}+\mathrm{Ph}$ groups, which were not inoculated with Salmonella, the lack of target cells probably led to the natural elimination of P22 few hours after inoculation. We hypothesize that P22 was not detected in $\mathrm{St}+\mathrm{Ph}$ and $\mathrm{St}+\mathrm{Pb}+\mathrm{Ph}$ groups after 24 hours due to the eradication of Salmonella by the treatments. Since the results obtained by Siqueira et al. ${ }^{26}$ support the idea that bacteriophage detection is a good method for detecting Salmonella, it is possible that the absence of P22 indicates the absence of Salmonella in the present study. Consequently, such results indicate that P22 was able to eradicate ST from the intestines of birds treated with $\mathrm{St}+\mathrm{Ph}$ since there was lack of microbiological recovery or PCR detection of either ST or P22.

These results are different from those reported in previous studies ${ }^{10,27-29}$ which revealed decreases in Salmonella CFU number when using bacteriophages as experimental treatment. Those authors used non-identified bacteriophages that, despite revealing success in reduction of Salmonella population, did not eradicate the pathogen. This feature is characterized by the possibility of using lentogenic bacteriophages, which could result in latency of the used bacteriophages by prophages insertion. Consequently, the Salmonella population would only be reduced by bacteriophages in lytic phase which can eradicate the pathogen. Thus, the use of bacteriophages is particularly encouraged in cases in which the bacteriophage species is known and present a lytic cycle, similarly to what was performed in the present study. Accordingly, our results indicate that the elimination of Salmonella - which is a major goal for the avian industry - can be achieved instead of the simple reduction in pathogen number.

In this study, we also tested the potential role of Lactobacilli probiotic as an experimental treatment in birds inoculated with ST. We found that the $\mathrm{St}+\mathrm{Pb}$ treatment performed in chicks was associated with Salmonella intestinal eradication after oral administration of a Lactobacilli mix. The inhibitory action of Lactobacillus used as a probiotic for prevention against Salmonella has been already demonstrated in vivo by other authors with success; $;^{30-33}$ however, despite other authors

Table 4. Mean of body weight of birds challenged against Salmonella Typhimurium and treated with probiotic and bacteriophage P22. Results are expressed in grams (g).

\begin{tabular}{|c|c|c|c|c|c|}
\hline Organ & Group & & riod after chal & enge (hours) ${ }^{a}$ & \\
\hline & & 0 & 48 & 96 & 144 \\
\hline Duodenum & $\begin{array}{c}\mathrm{Cr} \\
\mathrm{St} \\
\mathrm{Pb} \\
\mathrm{Ph} \\
\mathrm{St}+\mathrm{Pb} \\
\mathrm{St}+\mathrm{Ph} \\
\mathrm{St}+\mathrm{Pb}+\mathrm{Ph} \\
\mathrm{Pb}+\mathrm{Ph}\end{array}$ & $\begin{array}{l}1256.8 \pm 320.4 \mathrm{Cns}^{\mathrm{b}} \\
1215.8 \pm 280.4 \mathrm{Cnn}{ }^{\mathrm{c}} \\
1385.8 \pm 249.6 \mathrm{Bns} \\
1315.5 \pm 276.1 \mathrm{Cns} \\
1248.5 \pm 289.4 \mathrm{Bns} \\
1285.5 \pm 200.9 \mathrm{Cns} \\
1345.5 \pm 344.5 \mathrm{Bns} \\
1366.7 \pm 256.8 \mathrm{Bns}\end{array}$ & $\begin{array}{l}1335.9 \pm 371.2 \mathrm{Bb} \\
1278.0 \pm 309.4 \mathrm{Bb} \\
1689.3 \pm 379.3 \mathrm{Aa} \\
1293.7 \pm 382.1 \mathrm{Bb} \\
1667.9 \pm 349.1 \mathrm{Aa} \\
1256.9 \pm 258.6 \mathrm{Bb} \\
1692.9 \pm 342.9 \mathrm{Aa} \\
1785.2 \pm 301.9 \mathrm{Aa}\end{array}$ & $\begin{array}{l}1612.7 \pm 271.2 \mathrm{Ans} \\
1533.8 \pm 435.6 \mathrm{Ans} \\
1760.0 \pm 450.1 \mathrm{Ans} \\
1590.4 \pm 256.2 \mathrm{Ans} \\
1757.7 \pm 351.1 \mathrm{Ans} \\
1610.4 \pm 250.9 \mathrm{Ans} \\
1753.5 \pm 436.5 \mathrm{Ans} \\
1796.7 \pm 277.4 \mathrm{Ans}\end{array}$ & $\begin{array}{l}1211.7 \pm 429.2 \mathrm{Ans} \\
1697.3 \pm 358.5 \mathrm{Ans} \\
1921.0 \pm 490.5 \mathrm{Ans} \\
1722.9 \pm 379.8 \mathrm{Ans} \\
1908.5 \pm 454.9 \mathrm{Ans} \\
1745.6 \pm 290.1 \mathrm{Ans} \\
1900.6 \pm 374.8 \mathrm{Ans} \\
1033.2 \pm 310.9 \mathrm{Ans}\end{array}$ \\
\hline Cecum & $\mathrm{Cr}$ & $406.4 \pm 50.8 \mathrm{Cns}$ & $523.3 \pm 54.3 \mathrm{Bb}$ & $660.4 \pm 58.6 \mathrm{Ab}$ & $674.3 \pm 58.3 \mathrm{Ab}$ \\
\hline & St & $419.9 \pm 53.4 \mathrm{Bns}$ & $429.4 \pm 59.8 \mathrm{Bc}$ & $523.4 \pm 51.0 \mathrm{Ac}$ & $582.5 \pm 56.3 \mathrm{Ac}$ \\
\hline & $\mathrm{Pb}$ & $435.7 \pm 57.7 \mathrm{Cns}$ & $657.9 \pm 50.4 \mathrm{Ba}$ & $793.9 \pm 50.2 \mathrm{Aa}$ & $806.5 \pm 55.6 \mathrm{Aa}$ \\
\hline & $\mathrm{Ph}$ & $418.8 \pm 50.1 \mathrm{Cns}$ & $532.10 \pm 59.1 \mathrm{Bb}$ & $624.6 \pm 57.4 \mathrm{Ab}$ & $674.3 \pm 58.4 \mathrm{Ab}$ \\
\hline & $\mathrm{St}+\mathrm{Pb}$ & $405.4 \pm 52.6 \mathrm{Cns}$ & $616.2 \pm 60.0 \mathrm{Ba}$ & $693.9 \pm 60.5 \mathrm{Aa}$ & $748.4 \pm 57.8 \mathrm{Aa}$ \\
\hline & $\mathrm{St}+\mathrm{Ph}$ & $405.1 \pm 63.5 \mathrm{Cns}$ & $523.1 \pm 47.0 \mathrm{Bb}$ & $614.9 \pm 51.7 \mathrm{Ab}$ & $676.8 \pm 51.8 \mathrm{Ab}$ \\
\hline & $\mathrm{St}+\mathrm{Pb}+\mathrm{P}$ & 401.1 $\pm 37.2 \mathrm{Cns}$ & $616.6 \pm 41.4 \mathrm{Ba}$ & $729.1 \pm 57.8 \mathrm{Aa}$ & $832.9 \pm 59.1 \mathrm{Aa}$ \\
\hline & $\mathrm{Pb}+\mathrm{Ph}$ & $412.2 \pm 56.7 \mathrm{Cns}$ & $630.3 \pm 50.8 \mathrm{Ba}$ & $741.4 \pm 54.3 \mathrm{Aa}$ & $784.3 \pm 51.1 \mathrm{Aa}$ \\
\hline
\end{tabular}

aValues are arithmetic mean \pm standard deviation. ${ }^{b}$ Small letters compare the means of the treatments in each collection (column) and capital letters compare the means of the treatments during collections (lines). Values in a column and lines with different letters (e.g., a,b and c) differ significantly $(\mathrm{P}<0.05)$. ${ }^{\mathrm{N}, \text { no }}$ significant

have documented diminution in Salmonella population in birds treated with competitiveexclusion products, ${ }^{34}$ the use of Lactobacilli as treatment - instead of prevention - has not yet been documented.

In the present study, P22 and Lactobacilli probiotic mix was able to eradicate ST in the $\mathrm{St}+\mathrm{Pb}+\mathrm{Ph}$ group. Since groups inoculated with ST and treated with P22 (St+Ph) and Lactobacilli $(\mathrm{St}+\mathrm{Pb})$ alone revealed eradication of Salmonella, the eradication in $\mathrm{St}+\mathrm{Pb}+\mathrm{Ph}$ group was expected due to a possible synergic activity of those agents. Consequently, we suggest that the simultaneous use of a P22 bacteriophage and Lactobacilli probiotics mix is an interesting tool to be used as experimental treatment in chicks inoculated with Salmonella. Other authors ${ }^{35,36}$ also proposed the use of multiple biological agents as treatment for Salmonella by using a mix of competitive exclusion products with non-identified bacteriophages with consequent reduction in CFU number. Since the use of non-identified bacteriophages can result in the usage lentogenic bacteriophages instead of lytic ones.

Concerning weight of the chicks evaluated in this study, birds of $\mathrm{Pb}, \mathrm{St}+\mathrm{Pb}, \mathrm{Pb}+\mathrm{Ph}$, and $\mathrm{St}+\mathrm{Pb}+\mathrm{Ph}$ groups revealed weight gain means higher than those of the $\mathrm{Cr}$ group. Such results are in accordance with those observed by other authors ${ }^{37-41}$ who previously documented that birds receiving daily doses of Lactobacilli probiotics present higher weight gain rates when compared to non-supplemented birds. Additionally, those results are reinforced by Colichón et al. ${ }^{42}$ findings which demonstrated that oral administration of Lactobacillus in birds during the first days of life may increase weight gain up to $4.65 \%$.

In this study, the St group revealed a statis- tically significant weight loss in the very beginning of the experiment with subsequent weight gain. Such feature can be explained because paratyphus do not interfere in broiler chickens' productivity ${ }^{43}$ since those birds usually adapt itself to the infection. Despite $\mathrm{St}+\mathrm{Pb}$ and $\mathrm{St}+\mathrm{Pb}+\mathrm{Ph}$ groups were also inoculated with ST, birds in these groups did not reveal weight loss like chicks in St group. Such feature probably occurred because Salmonella eradication and Lactobacilli establishment in intestinal mucosa and lumen may have exercised beneficial effects similar to those already observed in $\mathrm{Pb}$ group.

Concerning morphological changes in the intestinal microenvironment, groups inoculated with Lactobacilli mix revealed significant increase in duodenal villi and cecal crypts size when compared to other groups. These features can be explained because probiotics stimulate proliferation of intestinal epithelial cells due to production of metabolytes produced by fermentative bacterial activity. Despite this, other authors ${ }^{45,46}$ did not observe differences in size of those structures between birds supplemented with Lactobacillus and those without supplementation. In those cases, the results probably occurred because Lactobacilli strains used may not have colonized intestinal mucosa and lumen.

The St group revealed significant alterations in length of cecal crypts with gradual recovery from disease, similarly to what was observed by other authors. ${ }^{46,47}$ Since intestinal mucosa is a barrier that protects organisms from intestinal pathogens ${ }^{48,49}$ a slower proliferation of intestinal epithelial cells and/or atrophy of the intestinal mucosa structures could facilitate the invasive process by secondary pathogens after Salmonella infection. Villous atrophy was also observed in histologi- 
cal sections, consequently justifying the diarrhea observed in birds during the first two days of experiment. Such clinical sign probably occurred due to alterations in mucosal hydrosaline equilibrium by blocking of $\mathrm{NaCl}$ absorption in microvilli and excretory stimulus of this salt through intestinal crypts cells. ${ }^{6,41}$ Despite this, body weight and intestinal microenvironment changes in were not observed $\mathrm{St}+\mathrm{Ph}$ and $\mathrm{Ph}$ groups. Such features probably occurred because bacteriophages do not interact with eukaryotic and/or bacteria other than its specific host. $^{2}$

\section{Conclusion}

Based on the findings of this study, we conclude that treatment with P22 bacteriophage and Lactobacilli can be effective in Salmonella eradication both combined and alone. We also conclude that oral administration of the P22 bacteriophage is effective in eradicating ST, promoting no perceivable alterations in birds' production or viability. Consequently, the experimental treatment here applied revealed itself as an interesting tool for ST control and eradication that can be further explored in order to be used in large scale in the Avian industry.

\section{References}

1. Lenski RE. Dynamics of interactions between bacteria and virulent bacteriophages. Adv Microbiol Ecol 1988;10:1-44.

2. Matsuzaki S, Rashel M, Uchiyama J, et al. Bacteriophage therapy: a revitalized therapy against bacterial infectious diseases. J Infect Chemother 2005;11:211-9.

3. Baxa U, Steinbacher S, Miller S, et al. Interactions of phage P22 tails with their cellular receptor, Salmonella 0-antigen polysaccharide. Biophys J 1996;71:2040-8.

4. Bayer ME, Takeda K, Uetake, H. Effects of receptor destruction by Salmonella bacteriophages 15 and c341. Virology 1980;105: 328-37.

5. Sulakvelidze A, Alavidze Z, Morris Júnior JG. Bacteriophage Therapy. Antimicrob Agents Chemother 2001;45:649-59.

6. Andreatti Filho RL, Fernandes SA, Boretti LP, et al. Sorovares de Salmonella isolados de materiais avícolas no período de 1994 a 1999. Rev Edu Cont CRMV-SP 2001;4:90 101.

7. Euzéby JP. Revised Salmonella nomenclature: designation of Salmonella enterica (ex Kauffmann and Edwards 1952) Le Minor and Popoff 1987 sp. nov., nom. rev. as the neotype species of the genus
Salmonella Lignieres 1900 (Approved Lists 1980), rejection of the name Salmonella choleraesuis (Smith 1894) Weldin 1927 (Approved Lists 1980), and conservation of the name Salmonella typhi (Schroeter 1886) Warren and Scott 1930 (Approved Lists 1980). Request for an Opinion. Int J Syst Bacteriol 1999;48:927-30.

8. Holt JG, Krieg NR, Sneath PHA, et al. Bergey's Manual of Determinative Bacteriology. 9th edn. Baltimore: Williams \& Wilkins. 1994.

9. Shelobolina ES, Sullivan SA, O'Neill KR, et al. Isolation, characterization, and U(VI)reducing potential of a facultatively anaerobic, acid-resistant bacterium from low$\mathrm{pH}$, nitrate- and U(VI)-contaminated subsurface sediment and description of Salmonella subterranea sp. nov. Appl Environ Microbiol 2004;70:2959-65.

10. Andreatti Filho RL, Higgins JP, Higgins SE, et al. Ability of bacteriophages isolated from different sources to reduce Salmonella enterica serovar Enteritidis in vitro and in vivo. Poult Sci 2007;86:1904-9.

11. Centers for Diseases Controls and Preventions. Investigation Update. 2009. Outbreak of Salmonella Typhimurium Infections, 2008-2009. Atlanta. Available from: http://www.cdc.gov/salmonella/ typhimurium/update.html

12. Andreatti Filho, RL. Paratifo Aviário. In: Saúde Aviária e Doenças. Andreatti Filho RL, São Paulo: Roca. 2007; pp. 96-111.

13. Fuller R. Probiotics in man and animals. J Appl Bacteriol 1989;66:365-78.

14. Elferink SJWHO, Krooneman J, Gottschal $\mathrm{JC}$, et al. Anaerobic conversion of lactic acid to acetic acid and 1,2-propanediol by Lactobacillus buchneri. Appl Environ Microbiol 2001;67:125-32.

15. Lindgren SE, Axelsson, LT, McFeeters RF. Anaerobic L-lactate degradation by Lactobacillus plantarum. FEMS Microbiol Lett 1989;66:209-13.

16. Collins EB, Aramaki K. Production of hydrogen peroxide by Lactobacillus acidophilus. J Dairy Sci 1980;63:353-7.

17. Lima ET, Andreatti Filho RL. Bacteriocins: nomenclature, detection, mechanism of action and potential use in poultry production. J Food Agr Environ 2005;3:62-6.

18. Skurnik M, Strauch E. Phage therapy: Facts and fiction. Int $\mathrm{J}$ Med Microbiol 2006;296:5-14.

19. Lima ET, Andreatti Filho RL, Okamoto AS, et al. Evaluation in vitro of the antagonistic substances produced by Lactobacillus spp. isolated from chickens. Can J Vet Res 2007;71:103-7.

20. Debartolomeis J, Cabelli VJ. Evaluation of an Escherichia coli host strain for enumeration of male-specific bacteriophages. Appl Environ Microbiol 1991;57:1301-5.
21. Mikasová E, Drahovská H, Szemes T, et al. Characterization of Salmonella enterica serovar Typhimurium strains of veterinary origin by molecular typing methods. Vet. Microbiol 2005;109:113-20.

22. Swamy SC, Barnhart HM, Lee MD, et al. Virulence determinants invA and spvC in salmonellae isolated from poultry products, wastewater, and human sources. Appl Environ. Microbiol 1996;62:3768-71.

23. Ferreira DF. Análises estatísticas por meio do Sisvar para Windows versão 4.0. In: 45a Reunião Anual da Região Brasileira da Sociedade internacional de Biometria. São Carlos: UFSCar. 2000; pp.255-258.

24. Berchieri Júnior A, Freitas Neto OC. Salmoneloses. In: Doenças das Aves, 2nd ed. Berchieri Júnior A, Silva EN, Di Fábio J, et al. Campinas: FACTA. 2009; pp. 43554 .

25. Zhang S, Kingsley RA, Santos RL, et al. Molecular pathogenesis of Salmonella enterica serovar Typhimurium-induced diarrhea. Infect Immun 2003;71:1-12.

26. Siqueira RS, Dodd CER, Rees CED. Phage amplification assay as rapid method for Salmonella detection. Braz J Microbiol 2003;34:118-20.

27. Atterbury RJ, van Bergen MAP, Ortiz F, et al. Bacteriophage therapy to reduce Salmonella colonization of broiler chickens. Appl Environ Microbiol 2007;73:45439.

28. Borie C, Albala I, Sánchez P, et al. Bacteriophage treatment reduces Salmonella colonization of infected chickens. Avian Dis 2008;52:64-7.

29. Fiorentin L, Vieira ND, Barioni Júnior W. Oral treatment with bacteriophages reduces the concentration of Salmonella Enteritidis PT4 in caecal contents of broilers. Avian Pathol 2005;34:258-63.

30. Gusils C, Perez Chaia A, Apella MC, et al. Antibacterial activity of Lactobacillus animalis isolated from chicken against Salmonella gallinarum. Microbiol Aliments Nutri 1998;16:265-73.

31. Higgins SE, Higgins JP, Wolfenden AD, et al. Evaluation of a Lactobacillus-based probiotic culture for the reduction of Salmonella Enteritidis in neonatal broiler chicks. Poultry Sci 2008;87:27-31.

32. Pascual M, Hugas M, Badiola JI, et al. Lactobacillus salivarius CTC2197 prevents Salmonella enteritidis colonization in chickens. Appl Environ Microbiol 1999;65:4981-6.

33. Vicente JL, Torres-Rodriguez A, Higgins SE, et al. Effect of a selected Lactobacillus spp.-based probiotic on Salmonella enterica serovar Enteritidis-infected broiler chicks. Avian Dis 2008;52:143-6.

34. Revolledo L, Ferreira CSA, Ferreira AJP. Comparison of experimental competitive- 
exclusion cultures for controlling Salmonella colonization in broiler chicks. Braz J Microbiol 2003;34:354-8.

35. Borie C, Sánchez ML, Navarro C, et al. Aerosol spray treatment with bacteriophages and competitive exclusion reduces Salmonella Enteritidis infection in chickens. Avian Dis 2009;53:250-4.

36. Toro H, Price SB, McKee S, et al. Use of bacteriophages in combination with competitive exclusion to reduce Salmonella from infected chickens. Avian Dis 2005;49:118-24.

37. Corrêa GSS, Gomes AVC, Corrêa AB, et al. Efeito de antibiótico e probióticos sobre 0 desempenho e rendimento de carcaça de frangos de corte. Arq Br Med Vet Zootec 2003;55:467-73.

38. Jin LZ, Ho YW, Abdullah N, et al. Growth performance, intestinal microbial populations, and serum cholesterol of broilers fed diets containing Lactobacillus cultures. Poultry Sci 1998;77:1259-65.

39. Kalavathy R, Abdullah N, Jalaludin S, et al. Effects of Lactobacillus cultures on growth performance, abdominal fat deposition, serum lipids and weight of organs of broiler chickens. Br Poult Sci 2003;44:139-44.

40. Ramírez Reyes B, Zambrano Santisteban
0, Ramírez Pérez Y, et al. Evaluación del efecto probiótico del Lactobacillus spp. origen aviar em pollitas de inicio reemplazo de la ponedora comercial en los primeros 42 días de edad. Rev Electr Vet 2005:6:090512.

41. Zacconi C, Scolari G, Sarra PG. Effect of administration of Lactobacillus salivarius and lactic microflora in chick digestive tract. Ann Microbiol Enzimol 1999;49:11723.

42. Colichón A, Columbus I, Roza M, et al. Efecto de la administración oral de Lactobacillus acidophilus vivos sobre el peso de ponedoras comerciales. Informe preliminar de los 30 primeros días de vida. Mundo Avícola 1991;1:8-10.

43. Silva EM. Salmoneloses em galinhas. In. Curso de Sanidade Avícola. Campinas: FACTA. 1993.

44. Sakata T. Stimulatory effect of short-chain fatty acids on epithelial cell proliferation in the rat intestine: A possible explanation for trophic effects of fermentable fibre, gut microbes and luminal tropic factors. $\mathrm{Br} \mathrm{J}$ Nutrit 1987;58:95-103.

45. Ferreira RN, Cavasin-Oliveira GM, Alves $\mathrm{CB}$, et al. Efeito da utilização de probiótico à base de Lactobacillus sp. sobre 0 ganho de peso e desenvolvimento da mucosa intestinal de ratos (Rattus norvergicus). Ciê Anim Br 2006;7:217-22.

46. Okamoto AS, Andreatti Filho RL, Lima ET, et al. Histopatologia da mucosa intestinal de pintos tratados com Lactobacillus spp. e desafiadas com Salmonella enterica, subespécie enterica, sorotipo Enteritidis. Ciê Anim Br 2009;10:568-73.

47. Andreatti Filho RL, Silva EN, Ribeiro AR, et al. Use of anaerobic cecal mi $\neg$ croflora, lactose and acetic acid for the protection of broiler chicks against experimental infection with Salmonella Typhimurium and Salmonella Enteritidis. Br J Microbiol 2000;31:107-12.

48. Alverdy JC, Aoys E, Moss GS. Effect of commercially available chemically defined liquid diets on the intestinal microflora and bacterial translocation from the gut. J Parenter Enteral Nutr 1990;14:1-6.

49. Deitch EA, Xu D, Naruhn MB, et al. Elemental diet and IV-TPN-induced bacterial translocation is associated with loss of intestinal mucosal barrier function against bacteria. Ann Surg 1995;221:299307. 